\title{
FACTORIAL STRUCTURE OF THE MORPHOLOGICAL STATUS OF FEMALE CADET HANDBALL PLAYERS
}

\author{
Miroljub Ivanović', Uglješa Ivanović \\ ${ }^{1}$ Serbian Academy of Innovation Sciences, ${ }^{2}$ Telekom Serbia, Itd Beograd
}

$\underline{\text { Original scientific paper }}$

\begin{abstract}
The aim of this research was to determine the constitution and the latent structures on the sample of 124 female handball players, age $13.72(S D=5.16)$. The measuring instruments of this transversal research included the set of 12 anthropometric variables (Mišigoj-Duraković, 1995). The descriptive methods with the statistical significance of $p \leq$ .05, as well as exploratory factor analysis (EFA), along with the Guttman-Kaiser Criterion for reducing the number of main components using the oblimin rotation of variables were used in the data processing. The obtained results revealed the existence of the relevant four-factor hierarchical model, with $71,44 \%$ of the explained variance. The first most informative latent dimension was interpreted as the factor of longitudinal dimensionality of the skeleton (explained $37.02 \%$ of the variability), the second was subcutaneous fat (20.25\% of the variability), the third is was body mass and volume $(7.86 \%$ of the variability), and the forth was transversal dimensionality of the skeleton $(6.31 \%$ of the explained variability). The factorial findings confirmed the hypothetical morphological structure of the extracted mutual factors of the participants, which is in accordance with the results of other researches. This study revealed practical implications and methodological limitations of this empirical research, and thus included recommendations for future research.
\end{abstract}

Key words: Morphological characteristics / younger female cadets / exploratory factor analysis / handball.

\section{INTRODUCTION}

In the last decade of the XXI century, sports results are being based on the hierarchical structure of the success factor, meaning on their basic anthropological markings, most of all on morphological characteristics which describe body constitution or somatotopic characteristics of an athlete. Anthropometric characteristics and body constitution of female handball players are the consequence of genetics and the way of adapting to training and diet. They have a relevant role in selection in junior categories, and in senior as well (Иваноивић и Ивановић, 2017; Masanovic \& Vukasevic, 2020; Минабутдинов \& Игнатьева, 2014, Naisidou et al., 2017). Therefore, early identification and the process of selecting talented female handball players and systematic monitoring of their development represent a significant prerequisite for athletic success (Corvino et al., 2014; Dopsaj et al., 2017; Fernández-Romero et al., 2017; Ивановић и Ивановић, 2015; Michalsik et al., 2015; Noutsos et al., 2019; Vuleta i sar., 2020). The condition for quality anthropological, primarily motor functioning in every athletic activity is the adequate constitution because motor skills are integrated to the morphological structure during the process of training. Certain characteristics of body constitution are intensely generated by the genetic factor (such as body height) while others, such as body mass, can be influenced by exogenic factors - training process and lifestyle (Moss et al., 2015; Grujić, 2016). The studies (Bojić-Ćaćić, 2019; Čavala, 2013;
Grujić, 2016) have shown that female players who have bigger hands, which is influenced by genetics, are more efficient in working the ball, meaning they are more successful in performing technical-tactical elements. Hence, in order for female adolescents to become top quality players, there needs to be a decade of professionally organized training and handball playing.

By applying the multivariate factorial concept, it can be claimed with great likelihood that the core of morphological space is four-dimensional. That means that it is structured from four factors: longitudinal dimensionality of the skeleton - responsible for bone growth in height, transversal dimensionality of the skeleton - which influences bone growth in width, body volume and mass - responsible for the total body mass and body circumference, and subcutaneous fat - responsible for total quantity of fat in the body (Ивановић и Ивановић, 2018). While analyzing the aforementioned latent dimensions, it should be taken into account that body height is a longitudinal component that is 85 to $90 \%$ genetically conditioned, and that means that it develops rapidly among girls age 11 to 13 (Michalsik \& Aagaard, 2015). That is the reason why knowledge of the morphological structure and its a influence on specific activity, as well as its contribution to the development of morphological characteristics, is necessary while planning the process of training an athlete. Based on the aforementioned research, it can be concluded that that the female beginner 
handball players need to be given direction for adequate anthropological markings, meaning adequate constitution, because their technicaltactical training cannot be realized without quality body shape that needs to continuously improve during the young female cadets' athletic career in order to prepare them for the more complex requirements needed in the junior category, and maximum efficiency in the senior category.

The aim of this empirical research was to examine the constitution and anthropometric structure of female handball players, age 13.72 \pm 5.16 . Based on the defined aim and the results of the previous studies, the initial hypothesis is formulated and it presupposes identifying the factorial hierarchical make-up of body composition of young female cadet handball players.

\section{RESEARCH METHODOLOGY}

\section{Participants sample}

The pertinent sample of participants included 124 female handball players from four handball clubs: WHC "Valjevo" (Valjevo), WHC "Bekament Bukovička Banja" (Aranđelovac), WHC "Kolubara" (Lazarevac), and WHC "Loznica-Grad" (Loznica). The average age of participants was $13.72(S D=5.16)$.

All participants had minimum two years of systematic and organized training, at least three times a week. All participants agreed voluntarily, and with their parents' consent, to take part in the research. Additional condition was that they are clinically healthy and without expressed motoric difficulties. Before the process began, the importance of the research was presented to both children and their parents.

\section{Morphological variables}

Anthropometric measuring has been conducted according to the protocol of Mišigoj-Duraković (1995) which is based on The International Biological Program (IBP) and World Health Organization (WHO). The standard set consisting of 12 anthropometric variables was chosen because of the hypothesis regarding the existence of four fundamental latent dimensions: longitudinal dimensionality of the skeleton body height (ALVT), arm length (ALDR), arm span (ALRR); transversal dimensionality of the skeleton - shoulder width (ATŠR), elbow diameter (ATDL), wrist diameter (ATDRZ); body volume and mass - body mass (AVTM), outstretched upper arm circumference (OVONA), forearm circumference (AVOPO); and subcutaneous fat - back skinfold (AKNL), upper arm skinfold (AKNN) and calf skinfold (AKNP).

\section{Statistical data processing}

Statistical analysis of the morphological profile of female handball players included the methods of descriptive statistics and multivariate exploratory method of factor analysis, where the number of relevant latent factors is defined by GuttmanKaiser criterion (GK), with oblimin rotation of variables.

\section{RESULTS AND DISCUSSION}

Table 1 shows the descriptive statistics parameters of anthropometric variables. The obtained values of the measurements of the shapes of distribution, skewness and kurtosis coefficients, or the ends of distribution of variables for the assessment of morphological characteristics indicate that there is normal Gaussian distribution of data compared to arithmetic mean, which enables further parametric procedures of data processing (Tabachnick \& Fidell, 2013).

With the aim of defining the construct (hypothetical) validity of 12 manifest morphological variables, meaning identifying latent anthropometric structure of the participants, exploratory factor analysis was conducted (Table 2).

By applying oblimin rotation and Kaiser normalization, four latent dimensions were extracted, which according to the authors (Schreiber, 2021) meets the Kaiser-Guttman criterion because they have the characteristic square $<1$. In addition, this interpretable fourfactor solution explains $71.44 \%$ of the total variance of the system of manifest anthropometric variables. This cumulative percentage of the root mean square deviation of the result of the measurements from their arithmetic mean shows that the isolated factors explain enough variance of the measuring variables, considering the chosen criterion. The residual part of the variance (28.56) of anthropometric measurements is most likely explained by the remaining part of the variability (specificity and accidental measurement error), meaning other specific factors that are in this case irrelevant (because their contribution, compared to the cumulative percentage of the explained variance, is relatively minimal).

The maximum quantity of the total variance was extracted by the first main component (37.78), and the second component explains $20.25 \%$ of the total variability, meaning that together they explain $52.27 \%$ of the total variation, while the third main component explains $7.86 \%$, and the fourth explains $6.31 \%$ of the total variance. 
Table 1. Descriptive statistics and data on skewness and kurtosis index of morphological variables

\begin{tabular}{|c|c|c|c|c|c|c|}
\hline Variables & Min & Max & $A M$ & $S D$ & $S \kappa$ & $K u$ \\
\hline ALVT $(\mathrm{cm})$ & 155.84 & 194.90 & 168.05 & 6.15 & .62 & .28 \\
\hline ALDR $(\mathrm{cm})$ & 64.96 & 85.95 & 71.97 & 4.23 & .26 & .47 \\
\hline ALRR $(\mathrm{cm})$ & 118.92 & 193.14 & 166.23 & 3.36 & .37 & .15 \\
\hline ATŠR $(\mathrm{cm})$ & 31.05 & 45.06 & 37.34 & 1.48 & .60 & .76 \\
\hline ATDL $(\mathrm{cm})$ & 5.97 & 6.90 & 6.37 & .95 & .30 & .38 \\
\hline ATDRZ $(\mathrm{cm})$ & 4.20 & 6.09 & 5.20 & .58 & .09 & .54 \\
\hline AVTM $(0.1 \mathrm{~kg})$ & 40.96 & 90.88 & 60.13 & 9.12 & .23 & .68 \\
\hline AVONF $(\mathrm{cm})$ & 22.87 & 33.06 & 26.95 & 2.86 & .44 & .70 \\
\hline AVONE $(\mathrm{cm})$ & 21.95 & 32.97 & 26.16 & 2.32 & .50 & .42 \\
\hline AVOPO $(\mathrm{cm})$ & 20.08 & 28.03 & 23.92 & 7.53 & .74 & .52 \\
\hline AKNL $(0.2 \mathrm{~mm})$ & 4.78 & 16.99 & 9.46 & 6.75 & .39 & .36 \\
\hline AKNN $(0.2 \mathrm{~mm})$ & 6.29 & 22.59 & 13.14 & 6.20 & .57 & .34 \\
\hline AKNP $(0.2 \mathrm{~mm})$ & 6.49 & 22.98 & 12.98 & 9.13 & .16 & .43 \\
\hline
\end{tabular}

Legend. $A M=$ arithmetic mean; $S D=$ standard deviation; $S K=$ standardized skewness; $K u=$ standardized kurtosis. The value of standard error SE with $S k$ is 0,15 , and with $K u$ is 0,23 . body height (ALVT), arm length (ALDR), arm span (ALRR); shoulder width (ATŠR), elbow diameter (ATDL), wrist diameter (ATDRZ); body mass (AVTM), flexed upper arm circumference (OVNAF) outstretched upper arm circumference (OVONE), forearm circumference (AVOPO), back skinfold (AKNL), upper arm skinfold (AKNN) and calf skinfold (AKNP).

Table 2. Initial characteristic values and percentage of the explained variance

\begin{tabular}{|c|c|c|c|}
\hline $\begin{array}{c}\text { Main } \\
\text { components }\end{array}$ & $\begin{array}{c}\text { Characteristic } \\
\text { square }(\lambda)\end{array}$ & $\begin{array}{c}\text { \% of the } \\
\text { explained } \\
\text { variance }\end{array}$ & $\begin{array}{c}\text { Cumulative \% of } \\
\text { the explained } \\
\text { variance }\end{array}$ \\
\hline 1 & 8.92 & 37.02 & 37.78 \\
\hline 2 & 4.05 & 20.25 & 57.27 \\
\hline 3 & 2.00 & 7.86 & 66.13 \\
\hline 4 & 1.45 & 6.31 & 71.44 \\
\hline
\end{tabular}

From the aspect of geometry, the resulting vector of the first characteristic square is the longest $(\lambda=8.92)$. It explains the biggest part of the proportion of the total squared standard deviation of all vectors of the analyzed morphological variables, because it is reduced by projections that have maximum variance, meaning maximum linear correlations with the measuring variables, which implies relatively valid informativeness of the somatic latent dimension "responsible" for its variability. However, even though the first main component explained the maximum percentage of the anthropometric space variance, the second, third, and fourth components also significantly contributed to explaining the variability of the group of manifest morphological variables.

Table 3 shows factorial load and communality of the four isolated latent dimensions. By applying oblimin rotation, the hierarchical four-factor structure was obtained, with the tendency on the one hand, that one factor correlates as much as possible with one set of the variables, or with the bundle if regarded as vectors, and on the other hand to correlate with other variables or vector bundles as little as possible (Golyandina,Nekrutkin \& Zhigljavsky, 2001). Taking an insight into the parallel projections of variables, which dominantly saturate certain vectors within the matrix of the correlation coefficient of the acute factorial axis, one can see the range from .84 to .90 for the first factor, .62 to .86 for the second, .71 to .75 for the third factor, while the range for the fourth isolated factor is from .65 to .69 .

In the final column of the Table, the communality of each measuring variable was calculated, meaning the proportion of the mutual variance of the variable which is common to all other variables together. The values of communality of the significant anthropometric measurements are high and they range from .65 to .90 which indicates to the reliability of the existence of the morphological latent dimensions. 
Table 3. Latent structure of the factors (factorial saturation) and communality

\begin{tabular}{|c|c|c|c|c|}
\hline Variables & $F 1$ & $F^{3}$ & $F 4$ & $h^{2}$ \\
\hline ALVT $(\mathrm{cm})$ & .81 & .29 & .24 & .90 \\
\hline ALDR $(\mathrm{cm})$ & .75 & .26 & .18 & .87 \\
\hline ALRR $(\mathrm{cm})$ & .83 & .21 & .27 & .84 \\
\hline ATŠR $(\mathrm{cm})$ & .60 & -.19 & .74 & .69 \\
\hline ATDL $(\mathrm{cm})$ & .19 & .05 & .80 & .67 \\
\hline ATDRZ $(\mathrm{cm})$ & .30 & .10 & .72 & .65 \\
\hline AVTM $(0,1 \mathrm{~kg})$ & .48 & .72 & .23 & .75 \\
\hline AVONE $(\mathrm{cm})$ & .51 & .76 & .17 & .73 \\
\hline AVOPO $(\mathrm{cm})$ & .19 & .83 & .09 & .71 \\
\hline AKNL $(0,2 \mathrm{~mm})$ &. .06 & .11 & .15 & .79 \\
\hline AKNN $(0,2 \mathrm{~mm})$ & .08 & .24 & .04 & .76 \\
\hline AKNP $(0,2 \mathrm{~mm})$ & .03 & .06 & .12 & .73 \\
\hline
\end{tabular}

Legend: $F 1,2,3,4=$ factorial saturation from the matrix $; h^{2}=$ communality.

It also indicates that communalities explain quite well the factor model of morphological latent dimensions because their manifest variables are linearly connected to other variables within the analyzed set.Maximum positive parallel projections of the very high intensity and communality for the first extracted latent dimension have manifest variables body height $(r$ $=.90)$, arm length $\quad(r=.87)$, and arm span $(r$ $=.84)$. In addition, the vectors of their variables form relatively narrow hypercone around the first main component and probably indicate that they share the identical subject of measuring, meaning that they include one relevant and mutual latent dimension within the factor model (Lorenzo-Seva \& Ferrando, 2021). Based on the calculated parameters which define the latent content of the first main component of the unipolar latent mechanism, it can hypothetically be interpreted as the mutual factor longitudinal dimensionality of the skeleton (responsible for skeleton growth in length) and is under the maximum influence of genetic factors. According to Noutsos et al (2019), this isolated factor of body composition depends most on genetic factors because its genetic coefficient has a high value $\left(H^{2}=.98\right)$, which means that kinesiological stimulus affect it only $2 \%$, and therefore the transformation of the muscle fibers, which are longitudinal characteristics of the skeleton, by the means of kinesiological stimulus and training processes is negligible.

The second isolated latent dimension is primarily defined by moderately high positive factorial saturation of the manifest variables: back skinfold (2.79), upper arm skinfold (.76) and calf skinfold (.73). Based on the projections of the variables and the size of the communalities on the second latent mechanism, its total variability can theoretically be defined as the factor of subcutaneous fat (important for the development of soft tissue, which is predominantly subcutaneous fat in the organism). The reduction of this latent dimension is under the influence of exogenic factors (optimal training volume) because the genetic coefficient for the subcutaneous fat is .50\% (Fernández-Romero et al., 2017).

The third latent dimension is determined by the correlation of moderate intensity between manifest variables body mass (.75), outstretched upper arm circumference (.73) and forearm circumference (.71). Based on the obtained statistically significant correlations between the original variables with the latent content of reduced latent homogenous structure, it is possible to hypothetically speaking name it the factor of circular dimensionality of the body volume and body mass (responsible for active body mass, circular dimensions of a body and the increase of body cross-section). Body mass is not genetically highly determined $\left(\mathrm{H}^{2}=.50\right)$, and training can influence its reduction, while the genetic coefficient for volume is .90\% (Weber \& Wegner, 2016).

The fourth extracted latent dimension is determined by the minimal percentage of the explained total result square deviation from their arithmetic mean, minimal intensity of the rotated factorial saturation and communality of the manifest variables shoulder width (.69), elbow diameter (.67) and wrist diameter (.65). Based on the contribution of the manifest variables which determine latent content of this main component, it can theoretically be mutually called the factor of transversal dimensionality of the skeleton (responsible for bone growth in width).

The obtained total variability, factorial saturations on the hierarchical extracted latent dimensions, as well as the communality on the manifest anthropometric variables presented in this research are in accordance with other researches (Bojić-Ćaćić, 2018; Bojić-Ćaćić et al 2018; Čavala, 2012; Massuça \& Fragoso, 2015; 
Šibila i Pori, 2009). Exploratory factor analysis of the collected data confirmed the initial hypothesis of this empirical research, which was the expectation that factorial morphological hierarchical body structure of young female cadet handball players would be identified. By identifying the morphological latent dimensions of the participants, the number of scientific information on the laws of forming an optimal anthropometric model of young cadet handball players of the female sex was increased and the more rational selection of handball players was enabled.

This research has a few methodological limitations. First, the chosen sample and the number of applied variables were relatively small and the sample included only female participants. In addition, reaching cause-andeffect conclusions in this research was impossible because the research is crosssectional, meaning correlational because data were collected at one moment in time. Therefore, future studies should be longitudinal and should be conducted on various categories of handball players, using both male and female representative samples, and with the greater number of anthropometric variables and participants.

\section{CONCLUSION}

The aim of this empirical research was to examine the morphological factorial structures of young female cadet handball players. The exploratory factor model reduced 12 manifest anthropometric variables, with $71.44 \%$ of statistically significant contribution of the total variability explained, to four latent dimensions. By predicting $37.02 \%$ of the variance of morphological variables, the first extracted main component was hypothetically determined as the factor of longitudinal dimensionality. It is maximally generated by genetic factors, and therefore kinesiological operators have minimum influence on their longitudinal dimensions of the skeletal structure. The second latent dimension explains $20.25 \%$ of the total variance, and it is determined by the factorial saturations of moderate intensity of the skinfold variables, and it is therefore interpreted as the subcutaneous fat factor. The transformation of this second main component can be significantly influenced by the training process because the genetic coefficient for subcutaneous fat is $.50 \%$. The second to last extracted latent dimension (volume and body mass) extracted $7.86 \%$ of the variability, while the last isolated main component transversal dimensionality of the skeleton explained $6.31 \%$ of the total variance of anthropometric variables. The obtained factorial findings confirmed the suggested hypothesis on the existence of mutual factors within the body composition of the participants. The anthropometric variables that were used proved themselves to be valid instruments to be used on the sample of female cadet handball players. The results obtained in this crosssectional study have possible theoretical and practical implications and show that there is a need for future research in order for us to fully understand anthropometric factorial structures among handball players.

\section{REFERENCES}

1. Bojić-Ćaćić, L. (2018). Position-related diferences in morphological characteristics of U14 female handball players. Kinesiology, 50(2), 235-242.

2. Bojić-Ćaćić, L. (2018). Antropološka obilježja odabranih rukometašica različite dobi. (Doktorska disertacija) Zagreb: Kineziološki fakultet.

3. Bojić-Ćaćić, L., Vuleta, D., Milanović, D., Barišić, V., \& Jerak, T. (2018). Age differences among the Croatian female young pivots in the indicators of basic and handball-specific physical fitness. In M. Baić, W. Starosta, P. Drid, J.M. Konarski, T. Krističević \& N. Maksimović (Eds.), 14th International Scientific Conference of Sport Kinetics 2018 "Movement in Human Life and Health": Proceedings (pp. 160-165). Zagreb; Novi Sad: Faculty of Kinesiology, University of Zagreb; Faculty of Sport and Physical Education, University of Novi Sad.

4. Corvino, M., Tessitore, A., Minganti, C., \& Sibila, M. (2014). Effect of court dimensions on players' external and internal load during small-sided handball games. Journal of Sports Science and Medicine, 13, 297-303.

5. Čavala, M. (2012). Morfološke, motoričke i psiho-socijalne karakteristike mladih rukometašica različite igračke kvalitete i pozicije. (Doktorska disertacija). Split: Kineziološki fakultet.

6. Grujić, S. (2016). Modelne karakteristike mladih rukometaša u odnosu na morfološka i motorička obeležja. (Doktorska disertacija). Sremska Kamenica: Fakultet za sport i turizam.

7. Golyandina N., Nekrutkin V., \&Zhigljavsky A. (2001) Analysis of time series structure: SSA and related techniques. London: Chapman \& Hall/ CRC.

8. Dopsaj, M., Valdevit, Z., llić, D., Pavlović, Lj., \& Petronijevic, M. (2017).Body structure profiles of r. of serbia's senior handballers from different competitive levels as measured by the multichannel 
bioelectric impedance method. Facta universitatis - series: Physical Education and Sport, 15(1), 49 $-61$.

9. Fernández-Romero, J. J., Vila Suárez, H., \& Cancela Carra, J. M. (2017). Selection of talents in handball: Anthropometric and performance analysis. Revista Brasileira de Medicina do Esporte, 23(5), 361-365.

10. Ивановић, М., и Ивановић, У. (2018). Гимнастика за здраво дете од рођења до 3. године, недоношчад и децу са тешкоћама у развоју. Сремска Митровица: Висока школа струковних студија за васпитаче и пословне информатичаре - Сирмијум.

11. Ивановић, М., и Ивановић, У. (2017). Мини-одбојка за децу од 6-12. године. Сремска Митровица: Висока школа струковних студија за васпитаче и пословне информатичаре Сирмијум.

12. Ивановић, М., и Ивановић, У. (2015). Мини-рукомет. Сремска Митровица: Висока школа струковних студија за васпитаче и пословне информатичаре - Сирмијум.

13. Lorenzo-Seva, U., \& Ferrando, P. (2021). Not Positive Definite Correlation Matrices in Exploratory Item Factor Analysis: Causes, Consequences and a Proposed Solution. Structural Equation Modeling: A Multidisciplinary Journalis, 28(1), 138-147.

14. Vuleta, D., Bojić-Ćaćić, L., Milanović, D., Mišigoj Duraković, M., \& Dizdar, D. (2020). Positional differences in anthropometric characteristics of the croatian u18 female field handball players. Kinesiology, 52 (1), 124-133.

15. Masanovic, B., \& Vukasevic, V. (2020). Differences in Anthropometric Characteristics between Junior Handball and Volleyball Players. J. Anthr. Sport Phys. Educ. 4(1), 9-14.

16. Massuça, L., \& Fragoso, I. (2015). Morphological Characteristics of Adult Male Handball Players Considering Five Levels of Performance and Playing Position. Collegium Antropologicum, 39(1), 109-118.

17. Michalsik, L.B., \& Aagaard, P. (2015). Physical demands in elite team handball: Comparisons between male and female players. Journal of Sports Medicine and Physical Fitrness, 55, 878-891.

18. Минабутдинов, Р.Р., Игнатьева, В.Я. (2014). Тестовые задания для контроля физической подготовленности гандболисток высокой квалификации. Теория и практика физической культуры, 4, 20-25.

19. Mišigoj-Duraković, M. (2008). Kinantropologija - Biološki aspekti tjelesnog vježbanja. Zagreb: Kineziološki fakultet Sveučilišta u Zagrebu.

20. Moss, S. L., McWhannell, N., Michalsik, L. B., \& Twist, C. (2015). Anthropometric and physical performance characteristics of top-elite, elite and non-elite youth female team handball players. Journal of Sports Sciences, 33(17), 1780-1789.

21. Naisidou, S., Kepesidou, M., Kontostergiou, M., \& Zapartidis, I. (2017). Differences of [in] physical abilities between successful and less successful young female athletes. Journal of Physical Education and Sport, 17(1), 294-299.

22. Norris, M., \& Lecavalier, L. (2010). Evaluating the use of exploratory factor analysis in developmental disability psychological research. Journal of Autism and Developmental Disorders, 40(1), 8-20.

23. Noutsos, S.K., Meletakos, G.P., \& Bayios, A.I. (2019). Morphological characteristics of adolescent elite female handball and volleyball players. Journal of Physical Education and Sport, 19(4), 15021507.

24. Schreiber, J. B. (2021). Issues and recommendations for exploratory factor analysis and principal component analysis. Research in Social and Administrative Pharmacy, 17(5), 1004-1011.

25. Šibila, M., Pori, P. (2009). Morphological Characteristics of Handball Players. Coll. Antropol. 33 (4), 1079-1086.

26. Tabachnick, B., \& Fidell, L. (2013). Using multivariate statistics. Boston: Pearson/Allyn \& Bacon.

27. Weber, J., \& Wegner, M. (2016). Konstitutionelle Anforderungen für verschiedene Spielpositionen beim Frauenhandball. Sportwissenschaft, 46(4), 305-314.

\section{Correspondence to:}

Miroljub Ivanović

Serbian Academy of Innovation Sciences, Višnjička 91a, 11060 Belgrad, Serbia,

Tel.: +381 64/875-28-32.

E-mail: miroljub.ivanovic@gmail.com 